\title{
Influence of seasonal changes in daily activity and annual life cycle of Geotrigona mombuca (Hymenoptera, Apidae) in a Cerrado habitat, São Paulo, Brazil
}

\author{
André L. Gobatto \& Fátima R. N. Knoll
}

Laboratório de Abelhas, Departamento de Biologia, Faculdade de Ciências da Universidade Estadual Paulista "Júlio de Mesquita Filho". Av. Eng. Luiz Edmundo Carrijo Coube, 14-01, 17033360 Bauru, São Paulo, Brasil. (andre gobatto@hotmail.com; knoll@fc.unesp.br)

\begin{abstract}
The foraging activity of Geotrigona mombuca Smith, 1863 was studied under natural conditions aiming to verify the influence of seasonal changes on daily flight activity and annual cycle of the colony. Daily flight activity was monitored for a year based on the observation and counting of foragers leaving and entering the hive, as well as the kind of material transported and meteorological factors such as day time, temperature and relative humidity. The influence of seasonal changes was evidenced by alterations on daily rhythm of flight activity and by differences on transportation of food resources, building material and garbage. These data indicate that forager behavior is related to daily microclimate conditions and it is synchronized with the requirements of colony annual cycle, which determines an intense pollen collection in the summer. Thus, the recomposition of the intranidal population in spring and summer can be ensured, which is characterized both for a higher intensity of flight activity and increase in garbage and resin transport, as well as the swarming process in the spring. In this way, an action targeting the preservation or management of the species in a natural environment should consider that survival and reproduction of the colony depends greatly on the amount of available pollen in late winter.
\end{abstract}

KEYWORDS. Meteorological factors, daily activity, seasonality, floral resources.

RESUMO. Influência das mudanças sazonais na atividade diária e no ciclo de vida anual de Geotrigona mombuca (Hymenoptera, Apidae) em hábitat de cerrado, São Paulo, Brasil. A atividade de forrageamento de Geotrigona mombuca Smith, 1863 foi estudada em condições naturais com o objetivo de verificar a influência das mudanças sazonais na atividade diária e no ciclo anual da colônia. A atividade diária de voo foi monitorada, durante um ano, através de contagens de campeiras observadas saindo e entrando na colmeia e o tipo de material transportado, juntamente com os fatores meteorológicos hora do dia, temperatura e umidade relativa do ar. A influência das mudanças sazonais foi constatada pela alteração do ritmo diário da atividade de voo e pelas diferenças no transporte de recursos alimentares, material de construção e de resíduos. Esses dados evidenciam que o comportamento das campeiras está relacionado às condições microclimáticas diárias e sincronizadas com as exigências do ciclo anual da colônia, o qual determina uma intensa coleta de pólen no verão, garantindo a recomposição da população intranidal na primavera e verão, caracterizada tanto pela maior intensidade de atividadede de voo como pelo aumento do transporte de resina e lixo, e enxameagem na primavera. Desse modo, ações direcionadas para a preservação da espécie em ambiente natural ou para o manejo devem considerar que a sobrevivência e reprodução da colônia depende muito da quantidade de pólen disponível no final do inverno.

PALAVRAS-CHAVE. Fatores meteorológicos, atividade diária, sazonalidade, recursos florais.

Geotrigona mombuca Smith, 1863, commonly known as Guira, nests in the unoccupied nests of ants from the genus Atta (NogueIRA-Neto, 1970; LACERDA et al., 1991). The entrance of the nest consists of a tube close to the ground, with dark wax, surrounded by sticks and clods (NogueIRA-Neto, 1970). An underground nest is comparatively more vulnerable than arboreal stingless bee nests (Meliponinae), which are more difficult to see and locate. These factors can partially explain the lack of studies on this species, since little is known beyond its description (CAMARGo \& MOURE, 1996), geographic distribution (CAmargo \& Pedro, 2013) and some aspects of intranidal biology (LACERDA et al., 1991).

The collection activity is directly or indirectly influenced by meteorological conditions, specially temperature, luminous intensity, relative humidity, rain and wind, and by biotic factors such as availability of floral resources, the insect's physiology and internal conditions of the colony, mainly food supply and queen productivity (HiLÁRIo et al., 2000; PEREBOOM \& BiesMeIJER, 2003; Nunes-SiLva et al., 2010). The study of external activities of foragers, besides providing essential data to support a better knowing of the ecology of this species, may be applied in an effective planning of agricultural plant pollination (IwAMA, 1977; BORGES \& BLOCHTEIN, 2005) and honey production (KeRR et al., 1996). For the present study, the focus was the aspects of the ecology of Geotrigona mombuca that are important for the species' preservation, providing useful information for its monitoring, management and beekeeping. In this way, the aim was to study the influence of seasonal changes on daily activity and annual life cycle of G. mombuca. For this purpose, the monitoring of forager movement was applied in order to quantify the flight activity and the kind of material carried and to relate these data with meteorological factors and seasonal changes.

\section{METHODOLOGY}

The study was carried out with a Geotrigona mombuca colony, found under natural conditions at Universidade Estadual Paulista, UNESP, Bauru Campus, state of São Paulo $\left(22^{\circ} 18^{\prime} 53^{\prime \prime} \mathrm{S}, 49^{\circ} 03^{\prime} 38^{\prime \prime} \mathrm{W}, \sim 580\right.$ $\mathrm{m})$. The flora on the campus consists of native species, fruit trees, ornamental and invasive plants. In an adjacent preservation area, the native vegetation is considered cerradão, presenting well-developed 
arboreal specimens (CAVASSAN, 2002). According to Köeppen classification, the local climate is "Cwa", i.e., tropical with two well-defined seasons - rainy and dry. Cwa is the dominant type in the largest area state of São Paulo, covering all of the central part of the state, and it is characterized by a highland tropical climate with rains in the summer and dry in the winter; the hottest month has an average temperature of higher than $22^{\circ} \mathrm{C}$. However, local data show climatic variation with the seasons of the year (Figueiredo \& Silveira Paz, 2010): in spring, hot afternoons with high humidity and the highest temperatures recorded in the year, increased precipitation, rainy days exceeding 13 days; in autumn, warm temperatures during night and early morning facilitate the occurrence of fog and damp mist, less rain (generally six days of rain) and a significant reduction of relative humidity; in winter, there is a higher variation in temperature range (around $19^{\circ} \mathrm{C}$ ) and relative humidity (below 30\%) due to the absence of rains.

Observations were performed by focal sampling, a method in which one or more individuals are observed for a specific time period. As sampling unity, the number of individuals counted for 10 minutes was considered. In one-hour intervals, from 7 a.m. to 6 p.m., the number of bees that came out over 10 minutes and that entered over 10 minutes was counted. This methodology was established in similar studies (OliveIRA, 1973; BORgES \& BlochteIn, 2005). Materials transported by the workers were recorded during the observation period. We identified pollen loads, resin and cerumen based on the characteristics of these materials (pollen = opaque, colourful and clearly defined mass; resin = shiny mass; cerumen $=$ irregular wax mass) and the garbage taken away from the hive with mandibles. The bees arriving without any visible materials were considered nectar collectors.

Meteorological factors such as relative humidity (UR\%) and temperature $\left({ }^{\circ} \mathrm{C}\right)$ were also measured at one-hour intervals at the beginning of counting, with a thermo-hygrometer located at Bees' Lab, about 70 meters from the nest entrance. Observations were performed every 15 days for a period of one year and two months (from September 11, 2008 to November 13, 2009).

For data analysis, samples of the counted foragers were grouped to provide information about the variation of daily and seasonal activity. Data from the total number of samples were analysed to verify the null hypothesis that the number of exiting bees is equal to the entering bees (from now on determined as entrance number), using the NPAR test Wilcoxon non-parametric test and Spearman's correlation for samples paired by time (ZAR, 1999). The relationship among flight activity (measured by the forager number) and the analysed abiotical factors (time, temperature and relative humidity) was verified by a quadratic polynomial nonlinear regression, where the geometric shape is a parable, fitting better to the interpretation of biological data (ZAR, 1999; SILVA et al., 2011). Finally, according to the type of transported material, the forage proportion was analysed to check possible diffences of these variables within and between seasons of the year (Kolmogorov-Smirnov test, $p<$ 0.05). All analyses were performed using the SPSS 17.0 statistical program.

\section{RESULTS}

A total of 10,059 foragers was recorded from the monitoring of exit and entrance movements of $G$. mombuca. From this, 5,332 were exiting movements and 4,727 were entrance movements, with an equal number of observation samples $(S=242)$. The majority of foragers coming out of the nest were not carrying any material (91\%), but some of them was transporting garbage $(6 \%)$ or wax $(3 \%)$. From entrance movements, there were foragers without material in the pollen basket and so considered nectar collectors $(62 \%)$, foragers carrying pollen (33\%) and resin (5\%).

Daily activity. Considering all the observation period, quadratic regression analysis did not differ statistically $\left(\mathrm{R}^{2}=0.015, \mathrm{p}=0.163\right)$ on exit movement intensity in relation to time (Tab. I). As expected, the correlation between exit and entrance number at the same time was high and statistically significant (Spearman Correlation, $\mathrm{r}=0.801, \mathrm{p}<0,01$ ). However, the exit number was higher than the entrance number at most times of the day, except at 12 p.m. and after 3 p.m. when the entrance number was higher (Fig. 1).

The confidence interval (CI 95\%) from the mean number of observed foragers was high at most times of the observation period, but it can be noted that the intensity of exit and entrance movements was higher between 1 and 3 p.m. (Fig. 1).

Concerning temperature, the flight activity was recorded from $16^{\circ} \mathrm{C}$, but forager movement started to be

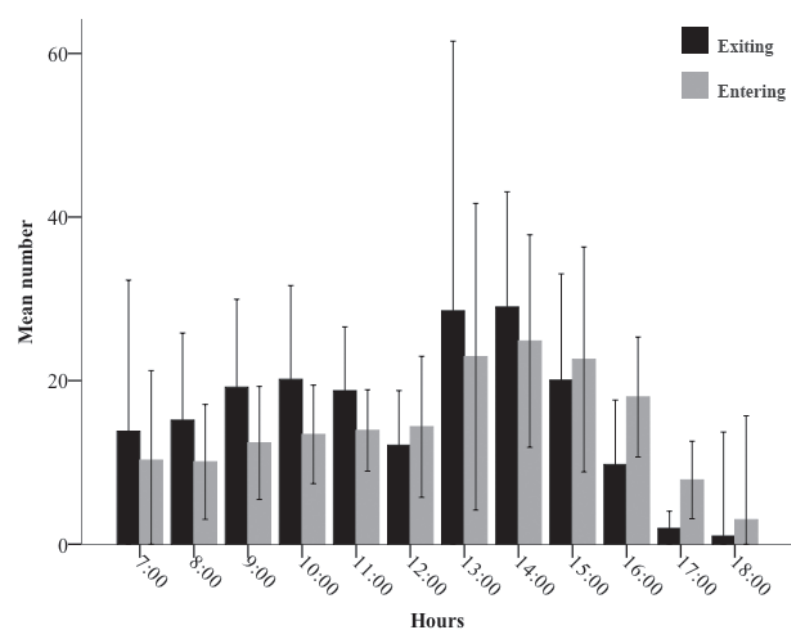

Fig. 1. Flight activity of Geotrigona mombuca Smith, 1863 in Bauru, state of São Paulo from 2008 to 2009: mean number of foragers observed exiting and entering the hive related to hours of the day (bars represent $95 \%$ of $\mathrm{CI}$ ). 
more intense at temperatures higher than $20^{\circ} \mathrm{C}$. At the upper limit, bees were observed up to $30^{\circ} \mathrm{C}$ (Fig. 2). The bees flew into a wide range of relative humidity, between $35-90 \%$. However, there was less variation of exit and entrance flow between $50-70 \%$ humidity (Fig. 3). The relation of exit movement with temperature and relative humidity was statistically significant $\left(\mathrm{R}^{2}=0.229 ; p<\right.$ 0.001 and $\mathrm{R}^{2}=0.239 ; p<0.001$, respectively), throughout the observation period (Tab. I). In addition, regarding temperature and relative humidity, the confidence interval (CI 95\%) of the mean number of observed foragers was high.

Analysing the relationships between abiotic factors and the involvement of foragers with the type of transported materials, it was observed that nectar collection was more affected by the variation of relative humidity $\left(\mathrm{R}^{2} 0.419, p<0.001\right)$, followed by temperature
$\left(\mathrm{R}^{2}=0.356 ; p<0.001\right)$ and was very little affected by daytime $\left(\mathrm{R}^{2}=0.043, p=0.004\right)$. In contrast, pollen collection showed relation with temperature $\left(\mathrm{R}^{2}=\right.$ $0.101, p<0.001$ ) (Tab. I). Concerning other types of materials transported by foragers (garbage, resin and wax), relationships with abiotic factors were low but statistically significant $(p<0.001)$. On the other hand, there was no statistically significant relationship $(p>$ 0.05 ) between bees involved in the swarming process and daily abiotic factors (Tab. I).

Seasonality. The data analysis from seasons of the year allowed a determination of the influence of abiotic factors on the number of hours, intensity of flight activity and priority of the material transported. Since there were no statistically significant differences between exit and entrance numbers (NPAR test Wilcoxon $=0.897, p=$ $0.05)$, only exit movement was considered to analyse

Tab. I. Quadratic regression and population parameters of Geotrigona mombuca Smith, 1863 in Bauru, São Paulo from 2008 to 2009 (R², coefficient of determination; F, test statistics; p, probability; b1, b2, partial regression coefficients) for the dependent variable number of foragers observed exiting the hive (by seasons and kind of activities) in relation the independent variables [hours, temperature $\left({ }^{\circ} \mathrm{C}\right)$, relative humidity $(\mathrm{RH}$ $\%$ ) and $\mathrm{S}$ (number of observation samples)].

\begin{tabular}{|c|c|c|c|c|c|c|}
\hline $\begin{array}{l}\text { Dependent } \\
\text { variable }\end{array}$ & $\begin{array}{l}\text { Independent } \\
\text { variable }\end{array}$ & $\left(\mathrm{R}^{2}\right)$ & $\mathrm{F}$ & $\mathrm{P}$ & b1 & b2 \\
\hline Total exit & Hours & 0,015 & 1,825 & 0,163 & 0,004 & $<0,001$ \\
\hline \multirow[t]{2}{*}{$(\mathrm{S}=242)$} & $\mathrm{T}\left({ }^{\circ} \mathrm{C}\right)$ & 0,229 & 35,373 & $<0,001$ & $-13,394$ & 0,387 \\
\hline & RH (\%) & 0,239 & 37,329 & $<0,001$ & $-7,65$ & 0,051 \\
\hline Nectar & Hours & 0,043 & 5,611 & 0,004 & 0,002 & $<-0,001$ \\
\hline \multirow[t]{2}{*}{$(\mathrm{S}=242)$} & $\mathrm{T}\left({ }^{\circ} \mathrm{C}\right)$ & 0,356 & 68,968 & $<0,001$ & $-19,015$ & 0,494 \\
\hline & RH (\%) & 0,419 & 89,976 & $<0,001$ & $-7,411$ & 0,049 \\
\hline Pollen & Hours & 0,001 & 0,144 & 0,866 & 0 & $<-0,001$ \\
\hline \multirow[t]{2}{*}{$(\mathrm{S}=242)$} & $\mathrm{T}\left({ }^{\circ} \mathrm{C}\right)$ & 0,101 & 13,421 & $<0,001$ & 2,821 & $-0,047$ \\
\hline & RH (\%) & 0,003 & 0,423 & 0,655 & $-0,248$ & 0,002 \\
\hline Resin & Hours & 0,034 & 4,133 & 0,017 & $9,50 \mathrm{E}-5$ & $<-0,001$ \\
\hline \multirow[t]{2}{*}{$(\mathrm{S}=242)$} & $\mathrm{T}\left({ }^{\circ} \mathrm{C}\right)$ & 0,176 & 26,768 & $<0,001$ & $-0,224$ & 0,009 \\
\hline & RH (\%) & 0,087 & 11,943 & $<0,001$ & $-0,171$ & 0,001 \\
\hline Debris & Hours & 0,046 & 6,032 & 0,003 & 0 & $<-0,001$ \\
\hline \multirow[t]{2}{*}{$(\mathrm{S}=242)$} & $\mathrm{T}\left({ }^{\circ} \mathrm{C}\right)$ & 0,108 & 15,126 & $<0,001$ & 0,164 & 0 \\
\hline & RH (\%) & 0,054 & 7,178 & 0,001 & $-0,111$ & 0,001 \\
\hline Cerumen & Hours & 0,006 & 0,747 & 0,475 & $<-0,001$ & $<0,001$ \\
\hline \multirow[t]{2}{*}{$(\mathrm{S}=242)$} & $\mathrm{T}\left({ }^{\circ} \mathrm{C}\right)$ & 0,003 & 0,322 & 0,725 & 0,253 & $-0,005$ \\
\hline & RH (\%) & 0,01 & 1,219 & 0,297 & $-0,132$ & 0,001 \\
\hline Exit in Spring & Hours & 0,124 & 7,347 & 0,001 & 0,009 & $<-0,001$ \\
\hline \multirow[t]{2}{*}{$(\mathrm{s}=107)$} & $\mathrm{T}\left({ }^{\circ} \mathrm{C}\right)$ & 0,05 & 2,739 & 0,069 & 19,875 & $-0,403$ \\
\hline & RH (\%) & 0,04 & 2,176 & 0,119 & $-4,891$ & 0,034 \\
\hline Exit in Summer & Hours & 0,121 & 3,659 & 0,032 & $-0,003$ & $<-0,001$ \\
\hline \multirow[t]{2}{*}{$(s=56)$} & $\mathrm{T}\left({ }^{\circ} \mathrm{C}\right)$ & 0,086 & 2,508 & 0,091 & 35,331 & $-0,739$ \\
\hline & RH (\%) & 0,011 & 0,282 & 0,755 & 0,854 & $-0,007$ \\
\hline Exit in Autumn & Hours & 0,054 & 0,576 & 0,571 & 0 & $<0,001$ \\
\hline \multirow[t]{2}{*}{$(\mathrm{s}=23)$} & $\mathrm{T}\left({ }^{\circ} \mathrm{C}\right)$ & 0,252 & 3,364 & 0,055 & 2,118 & $-0,051$ \\
\hline & RH (\%) & 0,002 & 0,022 & 0,978 & $-0,109$ & 0,001 \\
\hline Exit in Winter & Hours & 0,151 & 4,714 & 0,013 & 0,002 & $<-0,001$ \\
\hline \multirow[t]{2}{*}{$(\mathrm{s}=56)$} & $\mathrm{T}\left({ }^{\circ} \mathrm{C}\right)$ & 0,285 & 10,549 & $<0,001$ & $-6,28$ & 0,186 \\
\hline & $\mathrm{RH}(\%)$ & 0,443 & 21,052 & $<0,001$ & $-2,207$ & 0,014 \\
\hline
\end{tabular}




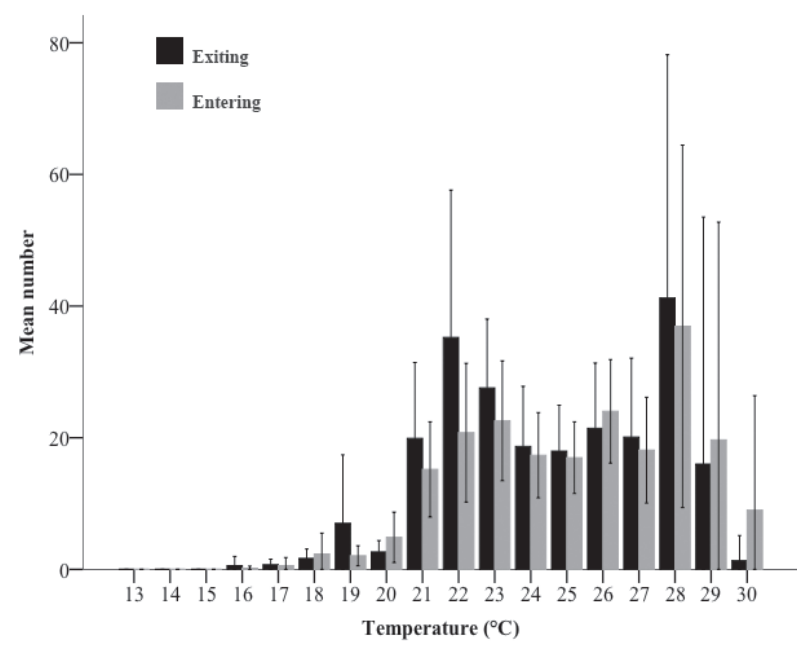

Fig. 2. Flight activity of Geotrigona mombuca Smith, 1863 in Bauru, state of São Paulo from 2008 to 2009: mean number of foragers observed exiting and entering the hive related to temperature $\left({ }^{\circ} \mathrm{C}\right)$ (bars represent $95 \%$ of $\mathrm{CI}$ )

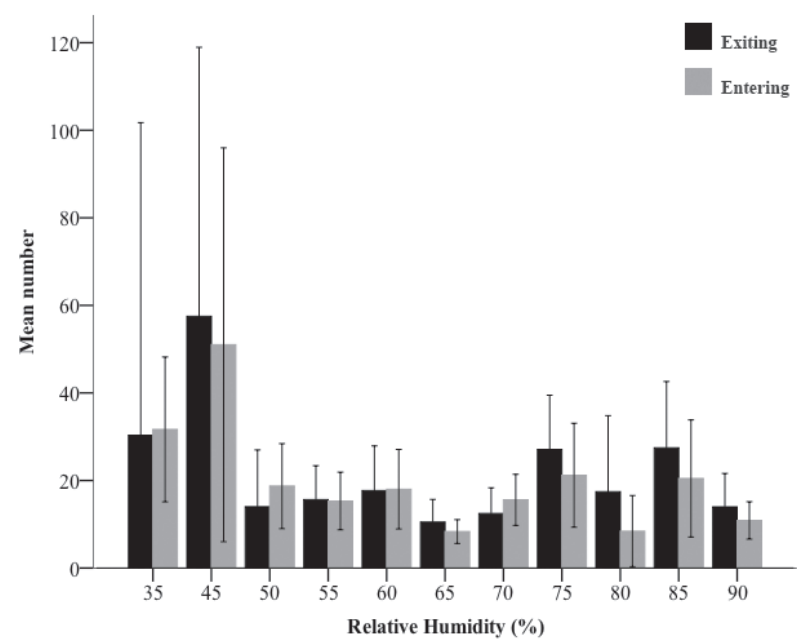

Fig. 3. Flight activityof Geotrigona mombuca Smith, 1863 in Bauru, state of São Paulo from 2008 to 2009: mean number of foragers observed exiting and entering the hive related to relative humidity (\%) (bars represent $95 \%$ of $\mathrm{CI}$ ).

how seasons of the year can alter relationships of flight activity with time and meteorological factors (Tab. I). In the spring, summer and autum it can be observed that the relationship between exit movement and meteorological factors was not statistically significant $(p<0.05)$. However, in the winter, forager activity was related to temperature $\left(\mathrm{R}^{2}=0.285, p<0.001\right)$ and to relative humidity $\left(\mathrm{R}^{2}=0.443, p<0.001\right)$. Daytime was statistically significant in the spring $\left(\mathrm{R}^{2}=0.124, p<\right.$ $0.001)$, summer $\left(\mathrm{R}^{2}=0.121, p<0.032\right)$ and winter $\left(\mathrm{R}^{2}=\right.$ $0.151, p<0.013)$ (Tab. I).

Number of flight activity daily hours varied throughout the seasons of the year, being lower in autumn (nine hours), followed by winter (10 hours) and can probably reach 12 hours in spring and summer (Fig. 4 ), since these seasons had bees returning to the nest on the first observation hour (7 a.m.). The flight intensity throughout the day also showed variations in the seasons of the year, clearly related to meteorological conditions described for each season of the studied site. In spring, a higher activity was observed during the first hours of afternoon; in summer, the higher activity was during the morning period; in autumn, there was little variation in the flight activity. In winter, there was a higher activity during the afternoon period, although with higher values of confidence interval (Fig. 4). These tendencies were confirmed by quadratic regression, where statistically significant correlations were obtained between exit movements and daytime in the spring $\left(\mathrm{R}^{2}=0.124, p=\right.$ $0.001)$, summer $\left(\mathrm{R}^{2}=0.121, p=0.032\right)$ and winter $\left(\mathrm{R}^{2}\right.$ $=0.151, p=0.013)$. Winter was the only season of the year in which there was a relation among flight intensity with temperature $\left(\mathrm{R}^{2}=0.285, p<0.001\right)$ and relative humidity $\left(\mathrm{R}^{2}=0.443, p<0.001\right)$ (Tab. I).

Generally, foraging activity showed differences in the mean number of foragers involved with material transport, both within and among seasons of the year (Fig. 5). Results of 40 comparisons revealed stistically significant differences in the number of foragers involved with each type of material transported (Kolmogorov-Smirnov test $=<0.001 ; p<0.05$ ). However, in the winter, there was no difference between the mean number of foragers involved in nectar and pollen collection (Kolmogorov-Smirnov test $=0.835$; $p<0.05$ ) and resin and garbage (Kolmogorov-Smirnov test $=0.624 ; p<0.05)$.

The effort of collection of nectar, pollen, resin, garbage and wax also showed statistically significant differences in relation to seasons of the year (KolmogorovSmirnov test $=<0.001 ; p<0.05)$. The nectar transport was higher in the spring, followed by summer. Pollen collection, nevertheless, was higher in the summer; garbage and resin were transported more during the spring and summer; wax was transported more in the spring (Fig. 5). Differences in intensity of the transported material were statistically significant for the majority of the 30 comparisons, except for nectar between autumn and winter (Kolmogorov-Smirnov test $=0.081 ; p<0.05)$, for pollen between spring and summer $(0.196 ; p<0.05)$ and between autumn and winter $(0.263 ; p<0.05)$.

\section{DISCUSSION}

According to RoubIK (1989), there are some factors influencing the external activity of social bees, such as daytime, meteorological factors, insect's physiology, mechanisms of nectar secretion and pollen production and floral quality and availability. Analysing the previous studies performed about Meliponini flight activity, SiLva et al. (2011) noted a consensus on small bees of this group being different from the foraging activity profile of Melipona large species, in similar flight conditions. Small size species show a high surface/ volume relationship, and so their metabolism is directly related to climate variations (OLIVEIRA, 1973; IWAMA, 


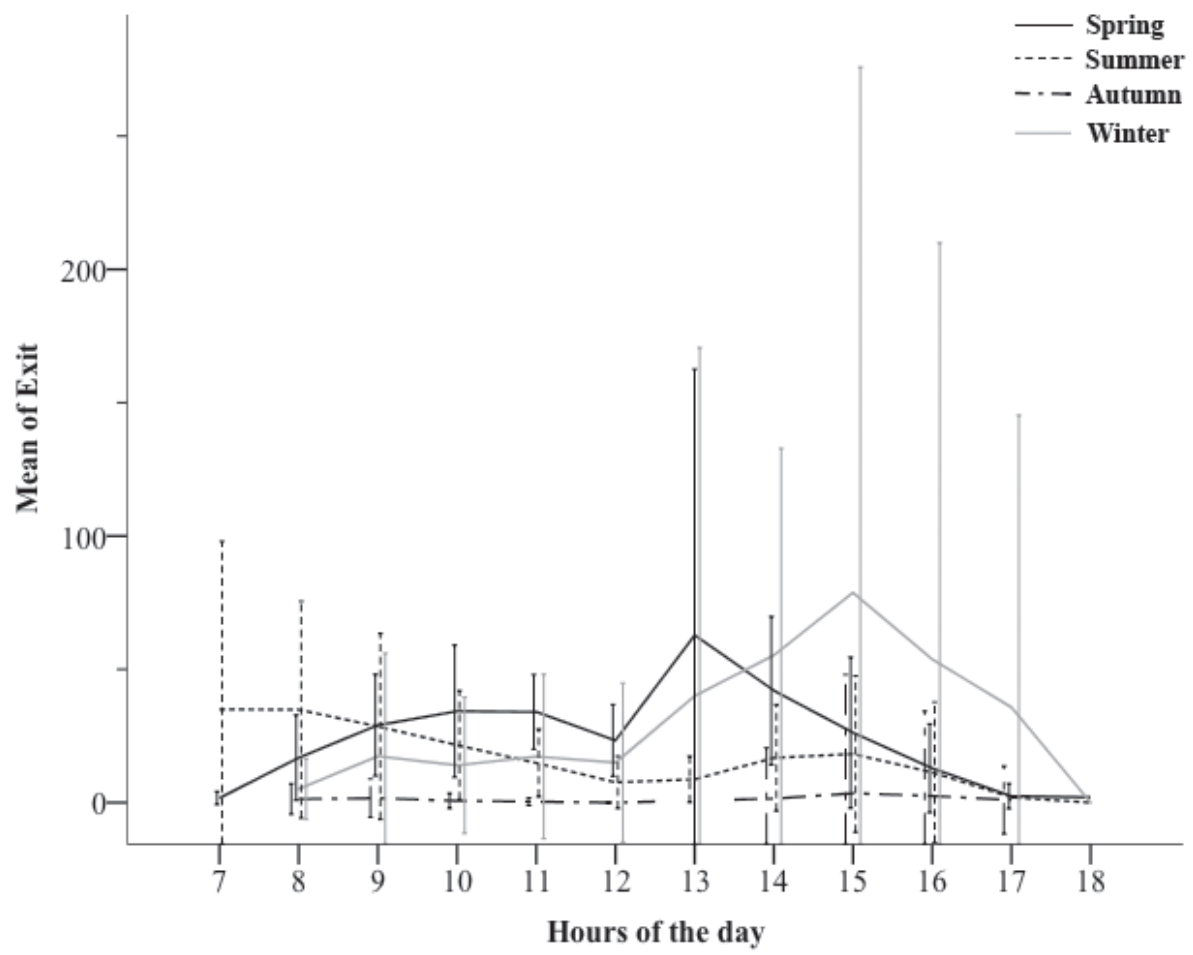

Fig. 4. Seasonal trends on flight activity of Geotrigona mombuca Smith, 1863 in Bauru, state of São Paulo from 2008 to 2009: mean number of foragers observed exiting the hive (Exit) related to hours of the day (bars represent $95 \%$ of $\mathrm{CI}$ ).

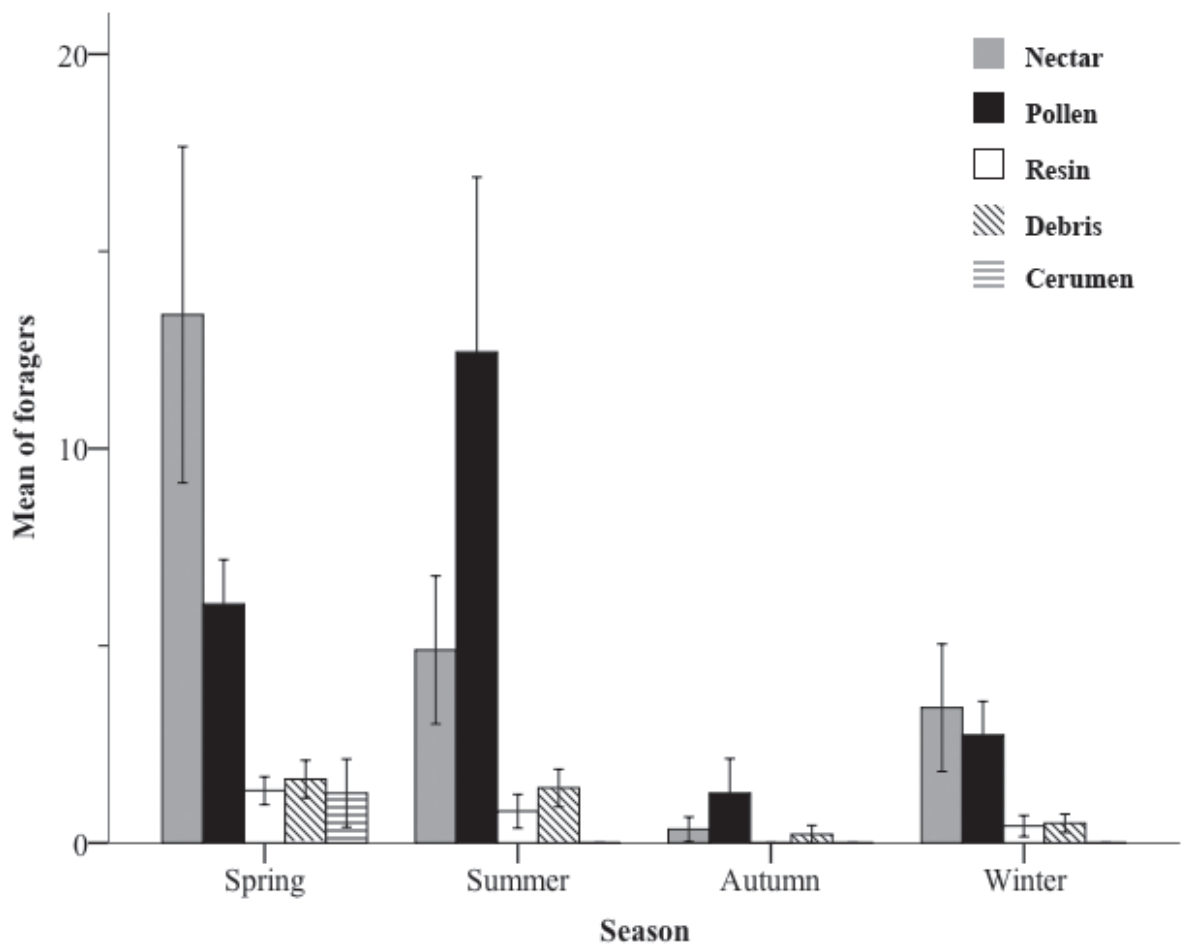

Fig. 5. Seasonal trends on the kind of material transported by Geotrigona mombuca Smith, 1863 in Bauru, state of São Paulo from 2008 to 2009 : mean number of foragers exiting (with debris and cerumen) and entering (with nectar, pollen and resin) the hive (bars represent $95 \%$ of $\mathrm{CI}$ ).

1977; Silva et al., 2011). Indeed, temperature and relative humidity, or both, are considered as influential factors on flight activity of several stingless bees of small size, including Tetragonisca angustula (Latreille, 1811), Plebeia saiqui (Friese, 1900), Plebeia droryana (Friese, 1900), Plebeia remota (Holmberg, 1903), Plebeia emerina Friese, Trigona carbonaria (Smith, 1854), T. hyalinata (Lepeletier, 1836) and Plebeia pugnax Moure (Oliveira, 1973; Iwama, 1977; KleINertGIOVANNINI, 1982; IMPERATRIZ-FONSECA et al., 1985; HeARD \& Hendrikz, 1993; Hilário et al., 2001; Pick \& Blochtein, 2002; Contrera et al., 2004). 
The results obtained in the present study for $G$. mombuca are similar to the activity pattern for the small bees stated above, especially for Paratrigona subnuda (Moure, 1947) (Mouga, 1984), a species with the same subterranean habitat. The biogeographic congruence shown by species of Paratrigona and Geotrigona reveals a possible common history (CAMARGo \& Moure, 1996), highlighting the tolerance to lower ranges of relative humidity and regular or effective activity from temperatures higher than $22^{\circ} \mathrm{C}$.

In the present study, for Geotrigona mombuca, the joint analysis of extensive data (for an extended period of months or years) exhibited different results than those obtained from data grouped by seasons of the year. Quadratic regression values from the relation of abiotic factors with flight activity and material transport where higher on the analysis of season of the year data, better reflecting the microclimate conditions. For the present study, concerning seasons of the year, in spring, summer and autumn there were no statistically significant relationships between exit movements and meteorological factors. However, in winter, forager activity was related to temperature and relative humidity. In this way, flight activity shall be subject to the meteorological factors that vary according to seasons of the year. As observed in the present study, some meteorological factors have more influence on more seasons than others (HiLÁRIo et al., 2001). In higher latitudes, where seasons are well defined, meteorological factors can influence both intensity and amplitude of daily flight activity (FERREIRA-JUNIOR et al., 2010).

According to our results, it seems that nectar collection was a determinant for the higher regression values with abiotic factors, considered here as annual data, since pollen collection showed a relation only with temperature, and other materials showed an almost null relation with the same factors. The higher relation between nectar collection and relative humidity can be partially explained by the prompt responses of floral nectaries to changes in relative humidity, being more liquid under high humidity and more viscous under low (KAKUTANi et al., 1989). In this way, collection efforts would be optimized when bees collect nectar with higher sugar concentrations. This fact can also explain the higher activity of foragers during the afternoon as observed in the winter. Likewise, higher activity of $G$. mombuca in the afternoon had been noted from casual observations (Nogueira-Neto, 1970), and it was confirmed in the present study.

Another relevant aspect is the interspecific competition for floral resources. There is evidence of a temporal division in the exploitation of floral resources throughout the day, based on body size and the consequent relationships with flight activity (BRUIJN \& SommeIJer, 1997; Hilário et al., 2000; SouZa et al., 2006; SiLva et al., 2011). The idea is that smaller size bees may also benefit from resources left by large size competitors, and this could partially explain the constancy of pollen collection during the day (SILVA et al., 2011). An alternative hypothesis would be the forager specialization in different kinds of material transported.

This discussion helps the comprehension of the results obtained for G. mombuca, small size species, with individuals of six milimetres (CAMARGO \& MOURE, 1996) and colonies with 2,000 and 3,00 individuals (LINDAUER \& KERR, 1960). It can be inferred here that residual nectar left by superior competitors, such as Apis mellifera and species of Trigona, be exploited by G. mombuca in order to avoid competition during the morning period. Fluctuations in the intensity of external activity of foragers of G. mombuca must probably occur due to these ecological and physiological restrictions.

Analysing the material transport behaviour throughout a year, it was possible to delineate the colony life cycle of G. mombuca. In later winter and early spring, there was a rapid increase in forager activity and the intensive pollen collection ensured the number of foragers maintained in spring and summer. In autumn, there was a period of reduced activity, maybe due to a reduction on the recomposition of intranidal population and due to the observed abiotic factors, together with the occurrence of fog in the morning, which in many days could delay the begining of the flight by two hours. In this way, the reproductive success of the colony in the next season depends on the pollen previously stored in summer and autumn. The cycle is completed with the population growth and swarming in spring, evidenced by wax transport to the daughter colony and the reproduction process of stingless bees commonly observed in spring and summer (Nogueira-Neto, 1970; Oliveira et al., 2013). Such information can help management plans for the species' preservation, which can be ensured under natural conditions by enriching local flora, or under artificial conditions through providing pollen in the diet.

Acknowledgements. The authors are grateful to Prof. Dr. Gabriel A. R. Melo, from the Laboratório de Biologia Comparada de Hymenoptera of Universidade Federal do Paraná (UFPR), for species identification.

\section{REFERENCES}

Borges, F. B. \& Blochtein, B. 2005. Atividades externas de Melipona marginata obscurior Moure (Hymenoptera, Apidae), em distintas épocas do ano, em São Francisco de Paula, Rio Grande do Sul, Brasil. Revista Brasileira de Zoologia 22:680-686.

Bruijn, L. L. M. \& SommeJer, M. J. 1997. Colony foraging in different species of stingless bees (Apidae, Meliponini) and the regulation of individual nectar foraging. Insectes Sociaux 44:35-47.

Camargo, J. M. F. \& Moure, J. S. 1996. Meliponini Neotropicais: o gênero Geotrigona Moure, 1943 (Apinae, Apidae, Hymenoptera), com especial referência à filogenia e biogeografia. Arquivos de Zoologia 33:95-161.

Camargo, J. M. F. \& Pedro, S. E. M. 2013. Meliponini Lepeletier, 1836. In: Moure, J. S.; Urban, D. \& Melo, G. A. R. eds. Catalogue of Bees (Hymenoptera, Apoidea) in the Neotropical Region. Curitiba, Sociedade Brasileira de Entomologia. p. 272 578. Available at: <http://www.moure.cria.org.br/catalogue $>$. Accessed on: 29 June 2013. 
Cavassan, O. 2002. O cerrado do Estado de São Paulo. In: Klein, A. L. org. Eugen Warming e o cerrado brasileiro: um século depois. São Paulo, Edusp e Imprensa Oficial do Estado, p. 93-106.

Contrera, F. A. L.; Imperatriz-Fonseca, V. L. \& Nieh, J. C. 2004. Temporal and climatological influences on flight activity in the stingless bee Trigona hyalinata (Apidae, Meliponini). Revista de Tecnologia e Ambiente 10:35-43.

Ferreira-Junior, N. T.; Blochtein, B. \& Moraes, J. F. De. 2010. Seasonal flight and resource collection patterns of colonies of the stingless bee Melipona bicolor schencki Gribodo (Apidae, Meliponini) in an Araucaria Forest area in southern Brazil. Revista Brasileira de Entomologia 54(4):630-636.

Figueiredo, J. C. \& Silveira PAZ, C. 2010. Nova classificação climática e o aspecto climatológico da cidade de Bauru/São Paulo. CBMet. Available at: <http://www.ipmet.unesp.br/4estacoes/\#>. Accessed on:24 July 2013.

Heard, T. A. \& Hendrikz, J. K. 1993. Factors influencing flight activity of colonies of the stingless bee Trigona carbonaria (Hymenoptera, Apidae). Australian Journal of Zoology 41:343353.

Hilário, S. D.; Imperatriz-Fonseca, V. L. \& Kleinert-Giovannini, A. 2000. Flight activity and colony strength in the stingless bee Melipona bicolor bicolor (Apidae, Meliponinae). Revista Brasileira de Biologia 60:299-306.

2001. Responses to climatic factors by foragers of Plebeia pugnax Moure (in litt.) (Apidae, Meliponinae). Revista Brasileira de Biologia 61:191-196.

Imperatriz-Fonseca, V. L.; Kleinert-Giovaninni, A. \& Pires, J. T. 1985. Climate variations influence on the flight activity of Plebeia remota Holmberg (Hymenoptera, Apidae, Meliponinae). Revista Brasileira de Entomologia 29:427-434.

IwAmA, S. 1977. A influência de fatores climáticos na atividade externa de Tetragonisca angustula (Apidae, Meliponinae). Boletim de Zoologia 2:189-201.

KaKUtAni, T.; InOUe, T. \& Kato, M. 1989. Nectar secretion patterns of the dish-shaped flower, Cayratia japonica (Vitaceae), and nectar utilization patterns by insect visitors. Population Ecology 31:381-340

Kerr, W. E.; Carvalho, G. A. \& Nascimento, V. A. 1996. Abelha uruçu - biologia, manejo e conservação. Belo Horizonte, Fundação Acangaú.143p.
Kleinert-Giovannini, A. 1982. The influence of climatic factors on flight activity of Plebeia emerina Friese (Hymenoptera, Apidae Meliponini) in winter. Revista Brasileira de Entomologia 26:113.

Lacerda, L. M.; Zucchi, R. \& Zucoloto, F. S. 1991. Colony condition and bionomic alterations in Geotrigona inusitata (Apidae, Meliponinae). Acta Biológica Paranaense 20(1-4):109123.

Lindauer, M. \& KerR, W. E. 1960. Communication between the works of stingless bees. Bee World 41:29-41, 65-71.

MougA, D. M. D. S. 1984. Atividade externa de Paratrigona subnuda (Hymenoptera, Apidae, Meliponinae). Ciência e Cultura 36:596597.

Nogueira-Neto, P. 1970. A criação de abelhas indígenas sem ferrão. 2ed. São Paulo, Chácaras e Quintais. 365p.

Nunes-Silva, P.; Hilário, S. D.; Pérsio de Souza, S. F. \& ImPeratrizFonsecA, V. L. 2010. Foraging activity in Plebeia remota, a stingless bee species, is influenced by the reproductive state of a colony. Psyche 1:1-17.

Oliveira, M. A. C. 1973. Um método para avaliação das atividades de vôo em Plebeia saiqui (Friese) (Hymenoptera, Meliponinae). Boletim de Zoologia e Biologia Marinha 30:625-631.

Oliveira, R. C.; Menezes, C.; Egea-Soares, A. E. \& ImperatrizFonseCA, V. L. 2013. Trap-nest for stingless bees (Hymenoptera Meliponini). Apidologie 44(1):29-37.

Pereboom, J. J. M. \& BiesmeiJer, J. C. 2003. Thermal constraints for stingless bee foragers: the importance of body size and coloration. Oecologia 137:42-50.

Pick, R. \& Blochtein, B. 2002. Atividades de voo de Plebeia saiqui (Holmberg) (Hymenoptera, Apidae, Meliponini) durante o período de postura da rainha e em diapausa. Revista Brasileira de Zoologia 19:827-839.

RoubIK, D. W. 1989. Ecology and Natural History of Tropical Bees. New York, Cambridge University Press. 514p.

Silva, M. D.; Ramalho, M. \& Rosa, J. F. 2011. Por que Melipona scutellaris (Hymenoptera, Apidae) forrageia sob alta umidade relativa do ar? Iheringia, Série Zoologia 101:131-137.

Souza, B. A.; Carvalho, C. A. L. \& Alves, R. M. 2006. Flight activity of Melipona asilvai Moure (Hymenoptera: Apidae). Brazilian Journal of Biology 66:731-737.

ZAR, J. H. 1999. Biostatistical analysis. New Jersey, Prentice-Hall.

Received 12 August 2013. Accepted 26 December 2013. ISSN 0073-4721

Article available at: www.scielo.br/isz 